\title{
Disorders of Sexual Development: Current Status and Progress in the Diagnostic Approach
}

\author{
Mary García-Acero Olga Moreno Fernando Suárez Adriana Rojas \\ Human Genetic Institute, Medicine Faculty, Pontificia Universidad Javeriana, Bogotá, Colombia
}

\section{Key Words}

Genetic pathway • Bipotential gonad • Sex differences •

Disorders of sexual development $\cdot$ Differential development

\begin{abstract}
Disorders of sexual development (DSD) are conditions with an atypical chromosomal, gonadal or phenotypic sex, which leads to differences in the development of the urogenital tract and different clinical phenotypes. Some genes have been implicated in the sex development during gonadal and functional differentiation where the maintenance of the somatic sex of the gonad as either male or female is achieved by suppression of the alternate route. The diagnosis of DSD requires a structured approach, involving a multidisciplinary team and different molecular techniques. We discuss the dimorphic genes and the specific pathways involved in gonadal differentiation, as well as new techniques for genetic analysis and their diagnostic value including epigenetic mechanisms, expanding the evidence in the diagnostic approach of individuals with DSD to increase knowledge of the etiology.

(c) 2020 The Author(s)

Published by S. Karger AG, Basel
\end{abstract}

\section{Introduction}

Phenotypic sex is the result of the differentiation of internal ducts and external genitalia under the function of the hormones of the differentiated gonad, this occurs once the gonad abandons its bipotential state under the influence of sex-determining genes [1]. Disorders of

\section{KARGER}

Fax +41613061234

E-Mail karger@karger.com

www.karger.com
(C) 2020 The Author(s)

Published by S. Karger AG, Basel Open access

This article is licensed under the Creative Commons AttributionNonCommercial-NoDerivatives 4.0 International License (CC BYNC-ND) (http://www.karger.com/Services/OpenAccessLicense).
Usage and distribution for commercial purposes as well as any distribution of modified material requires written permission. sexual development (DSD) were defined in the Chicago Consensus, 2006 as congenital conditions in which the development of chromosomal, gonadal and anatomical sex is atypical [2]. The term has positive aspects such as accuracy within the medical context, as well as avoid confusion by not overlapping with conditions such as transgender, gender dysphoria and homosexuality. However, negative connotations of DSD perceived by patients include the stigma of "disorder" and the perceived implications of "sex" involving sexual behavior [3]. The clinical classification in patients is difficult because the phenotypes are similar or almost identical and may have several etiologies $[4,5]$. Due to the lack of clarity of the term, there is no certainty of the incidence of the conditions included. It has been estimated that its individual incidence is approximately 1 in 4,500-5,500 newborns [6] and when considering all genital congenital anomalies, including cryptorchidism and hypospadias, the incidence can be from 1:200 to 1:300 [7]. The incidence of DSD in 46,XY individuals has been estimated in 1 in 20,000 births and the global incidence of DSD in 46,XX individuals (mainly congenital adrenal hyperplasia) is 1 in 14,000-15,000 live births [8], which varies by region due to differences in the frequency of pathogenic variants. Congenital adrenal hyperplasia and mixed gonadal dysgenesis constitute half of all patients with DSD which clinically present with genital ambiguity [9].

These conditions can be identified at different times of life, in fetuses or newborns with ambiguous external genitalia, gonadal dysgenesis and internal genitalia that are discordant for the constitution of sexual chromosomes, also can be subsequently diagnosed in individuals with

Adriana Rojas

Human Genetic Institute, Pontificia Universidad Javeriana Bogotá (Colombia)

E-Mail rojas.adriana@javeriana.edu.co 
Table 1. Classification of DSD

\begin{tabular}{|c|c|c|c|c|}
\hline \multirow[b]{2}{*}{ DSD sex chromosomes } & \multicolumn{2}{|c|}{ DSD 46,XY } & \multicolumn{2}{|c|}{ DSD 46,XX } \\
\hline & $\begin{array}{l}\text { Disorders of testicular } \\
\text { development }\end{array}$ & $\begin{array}{l}\text { Disorders of the synthesis/ } \\
\text { action of androgens }\end{array}$ & $\begin{array}{l}\text { Disorders of ovarian } \\
\text { development }\end{array}$ & $\begin{array}{l}\text { Disorders of the } \\
\text { synthesis/action }\end{array}$ \\
\hline $\begin{array}{l}\cdot 45, \mathrm{X} \text { Turner syndrome and } \\
\text { variants } \\
\cdot 47, \mathrm{XXY} \text { Klinefelter syndrome } \\
\text { and variants } \\
\cdot \text { • } 45, \mathrm{X} / 46, \mathrm{XY} \text { GMD } \\
\cdot \text { Ovotesticular DSD }\end{array}$ & $\begin{array}{l}\cdot \text { complete gonadal } \\
\text { dysgenesis } \\
\text { - partial gonadal dys- } \\
\text { genesis } \\
\text { - gonadal regression } \\
\text { - ovotesticular DSD }\end{array}$ & $\begin{array}{l}\text { - defect in androgen synthesis } \\
\text { - LH receptor defect } \\
\text { - insensitivity androgens } \\
\text { - } 5 \alpha \text { reductase deficiency } \\
\text { - disorder AMH } \\
\text { - cloacal extrophy }\end{array}$ & $\begin{array}{l}\text { - ovotesticular DSD } \\
\text { - testicular DSD } \\
\text { - gonadal dysgenesia }\end{array}$ & $\begin{array}{l}\text { - congenital adre- } \\
\text { nal hyperplasia } \\
\text { - aromatase defi- } \\
\text { ciency } \\
\text { - maternal luteoma }\end{array}$ \\
\hline
\end{tabular}

Adapted from consensus on management of intersex disorders, 2006 [2].

late puberty, unexpected virilization or gynecomastia, infertility or gonadal tumors. Occasionally, DSD may be part of a genetic syndrome, demonstrating the complexity of sexual development and the effect of multiple genes.

In recent years, research in DSD has focused on the identification of genetic variants that lead to the atypical development of sex through different techniques. However, sequencing, deletion and duplication analysis have identified causality in near of $50 \%$ of cases $[10,11]$. It is likely that this diagnostic gap exists due to inadequate knowledge of the pathogenesis and underlying mechanisms of DSD, variation in evaluation and phenotypic description, and limited awareness of the value of molecular genetic diagnosis to guide management and treatment of the individual.

The challenges facing the genetics of DSD include the development of a diagnostic algorithm that integrates various technologies (including transcriptomics, epigenomics, proteomics and metabolomics), so that the etiology of the entity can be established. This review will discuss basic concepts of DSD and the advances in the diagnostic approach of this entity.

\section{Classification of DSD}

DSD are classified according to the alterations in the levels of sex designation: gene sex, chromosomal sex, gonadal sex, hormonal sex, ductal sex, external genitalia, secondary characters, legal assigned sex and psychological characteristics [12]. However, clinical management is carried out in accordance with the classification proposed by the Pediatric Endocrinology Society Lawson Wilkins and the European Society of Pediatric Endocrinology (table 1) as follows: 1) DSD sex chromosomes, 2) DSD 46,XX and 3) DSD 46,XY. Despite the classification some conditions do not fit exactly into a specific diagnostic category or may belong to more than one category [1].

\section{Pathophysiology}

Sexual determination is the result of molecular events that direct the undifferentiated bipotential gonad to the development of the testis or ovary. The bipotential gonad is developed from the urogenital crest, between weeks 6 to 7 of fetal life, when there are 2 sets of internal ducts: Müllerian ducts and Wolffian ducts [13, 14]. During the bipotential stage, several genes (WT1, DAX1, SF1, LHX9, LIM1, PAX2, GATA4, EMX2, WNT4) are expressed in the gonadal crests XY and XX. The function of protein products of these genes, gene dosage and the resulting levels of gene expression determine gonadal differentiation [15-17], in response to the activation of the testis-specific or ovary-specific pathway with parallel repression of the opposite pathway. The genitalia external to this age present a genital tubercle, genital folds, urethral folds and a urogenital orifice.

Several genes upstream of $S R Y$ not sex-specific are early expressed in the gonadal and are essential for sexual development; in fact, absence of some of these genes leads to sex reversal [18]. There is evidence in animal models of pregonadal sexual differentiation independent of determination by $S R Y$ expression. The results of analysis in vitro of fertilized embryos show early evidence of sexual dimorphism. Yadav et al. [19] found that the first embryos performing the one-cell division were significantly more likely to be male than female, being XY 


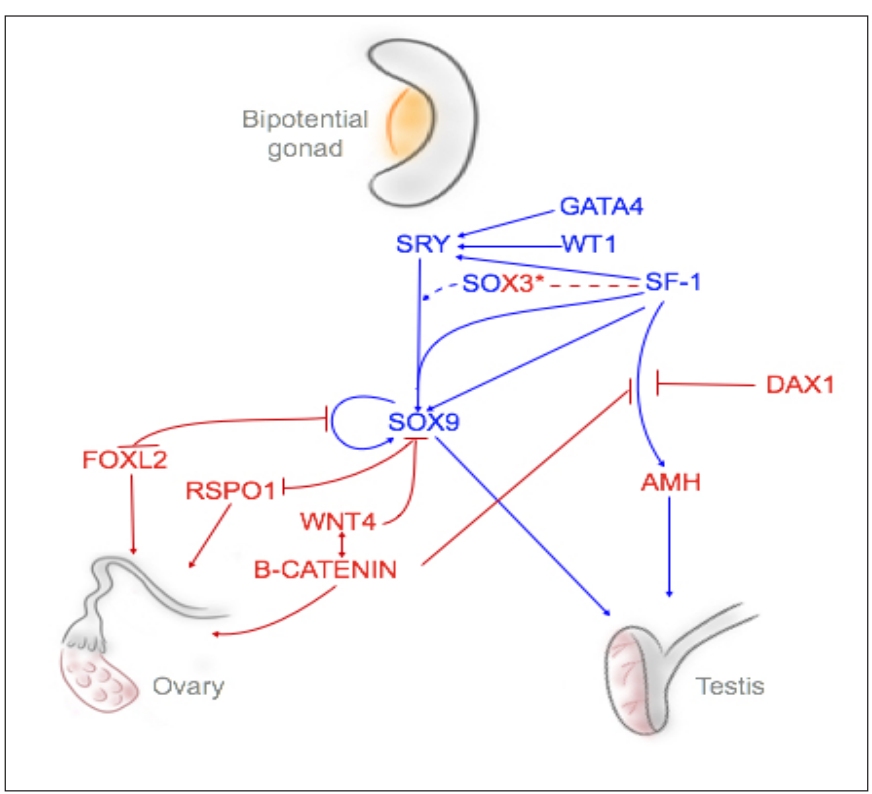

Fig. 1. Proposed scheme of gene regulation in gonadal development. No sexual difference can be observed in the gonads until the 6th week of embryonic life in humans. Genes related to testicular development (blue) and genes related to ovarian development (red). Arrows do not necessarily imply direct actions. In XY gonads, * $S O X 3$ may act in development of male gonad by acting like $S R Y$. SOX 9 expression is subsequently upregulated by $S R Y$ and $S F-1$ binding to TESCO region of this gene. SOX 9 regulates the expression of genes required for testis formation, also suppresses the expression of ovarian genes such as RSPO1 and FOXL2. In $\mathrm{XX}$ gonads $* S O X 3$ may act in development of female gonad by inhibition of SOX9. The genes RSPO1, FOXL2, WNT4 and $\beta$-catenin are also expressed in a female-specific manner, promoting ovarian development and preventing differentiation of testis by repressing $S O X 9$ expression. Hypothesis of interaction of $S O X 3$ was proposed in reference to animal models of sex development and few reports of human with pathogenic variants in this gene [48].

mouse embryos fastest in cell division than XX embryos, the findings have already been confirmed in humans [20] and it is associated with the paternal X chromosome that has a retarding effect in post implantation embryos [21].

Some factors also have a work early in the development, as have been demonstrated to the insulin receptor in the male sexual differentiation [22], required to gonadal proliferation before $S R Y$ expression.

Later, 2 proteins that play a major role in the development of the bipotential gonad are the nuclear receptor SF-1 (also known as NR5A1) and the Wilms tumor suppressor (WT1). The steroidogenic factor 1 (SF-1) is important for the synthesis of adrenal and gonadal steroids and it is expressed in the bipotential gonad of both sexes.
Its expression continues in the developing testes, but it is repressed in the ovary, which hypothetically linked the expression of $S R Y$ with that of the antimüllerian hormone (AMH) [23]. The WT1 gene encodes a necessary transcription factor for mesenchymal-epithelial interactions and secondary development of the bipotential gonad (interactions between Sertoli cells and Leydig cells) [24].

Other genes implicated in gonadal differentiation, with transcripts present in the urogenital ridges are DMRT1, PAX2, LHX9. Pathogenic variants in these genes does not form a gonad because the somatic cells of the genital ridge fail to proliferate despite normal germ cell migration [25]. Other genes of gonadal differentiation include $S O X 3$, SOX9, FGF9 and PGD2 which have more testicular-promoting activity [26-28]. The DAX1, WNT4, FOXL2, RSPO1 and $\beta$-catenin genes are predominantly ovarian promoters [16, 29-31].

\section{Testis Development}

Male differentiation is a 2-step process [32], determined by: 1) testis formation from primitive gonad through various transcription factors known as sex determination, and 2) differentiation of internal and external genitalia by action of hormones secreted by the fetal testicle know as sex differentiation, which include the action of AMH secreted by Sertoli cells, androgens and insulin-like factor-3 secreted by Leydig cells.

Testicular formation depends on $S R Y$, a gene that encodes a sufficient and necessary transcription factor to induce testicular development. After translation, the SRY protein translocate to the nucleus and binds to the enhancer region of SOX9, to intervene in the differentiation and proliferation of Sertoli cells and the tubular organization of the testis [33, 34] (fig. 1). Pathogenic variant or loss of $S R Y$ gene function result in male to female sexual reversion or in coexistence of ovarian and testicular tissues [35]. Being the most of pathogenic variants detected in the $S R Y$ gene localized in the DNA binding domain [36]. Similarly, $S R Y$ expression in XX individuals by chromosomal translocation has been reported to account for $10 \%$ of female to male sex reversals and that pathogenic variants in the $S R Y$ gene are responsible for $15 \%$ of cases of gonadal dysgenesis in $46, X Y$ individuals [37]. Failure of $S R Y$ expression can also be caused by pathogenic variant in genes involved in chromatin structure, like polycomb complexes, which help to maintain the undifferentiated state of embryonic stem cells by inhibiting the expression of many genes [38], or genes pro- 
posed to alter SRY expression as GATA4 and its partner FOG2 [39]. When alterations occur at the gonadal level, it causes anatomic, physiological and functional defects of the gonad as complete gonadal dysgenesis or mixed gonadal dysgenesis [38].

Gene targets of $S R Y$ are SOX9, CBLN4, and ER71/ ETV2; being perhaps the most important target gene $S O X 9$. Activation of $S O X 9$ is produced by the joint action of the $S R Y$ and $S F-1$ proteins on the TESCO region (testicular enhancer specific of Sox 9 core) [32]. Likewise, it has been established that the $S O X 9$ protein can bind to its own promoter, modulating its own expression [38]. Although the relationship between SRY and SOXY is narrow, testicular formation can occur in the absence of SRY, which has been observed in XX men who have duplications and/or translocations of $S O X 9$, as well in $\mathrm{XX}$ mice transgenic for $S O X 9$ [41]. Studies related to gene expression showed a decrease in $S O X 9$ protein expression and absence of pathogenic variant in several regions of the gene promoter (TESCO region) in 75 Brazilian patients with karyotype 46,XY and sexual reversion [42] which may indicate other mechanisms of gene regulation as etiology. Unlike the expression of SRY in the developing gonad which is transient, the expression of SOX9 occurs after its initial induction and remains positive.

Also, belonging to the $S O X$ family, the $S O X 3$ gene, similar in structure and function to the $S R Y$ gene $(67 \%$ nucleotide identity and absence of introns), has transactivating activity and works synergistically with $S F-1$ for testicular differentiation (fig. 1). Despite the evidence, the role of SOX3 in sexual determination is still unclear and the available information is only based on animal models [43]. However, it has been shown that SOX3 is expressed in both the XX and XY mouse gonads during the critical period of sexual determination [44]. From this, it has been proposed that $S O X 3$ acts as a repressor of SOX9 expression during female determination and that $S R Y$ expression removes $S O X 9$ repression by acting as a $S O X 3$ repressor in male individuals $[45,46]$. It has been described that one way in which $S R Y$ could affect or inhibit $S O X 3$ activity would be by competition for DNA binding sites $[47,48]$. In male mice, $S O X 3$ has been found to be necessary for the normal formation of the seminiferous tubules and for the normal function of Sertoli cells, supported with the results of SOX3-deficient mice, which exhibit anomalies in testicular histology with small tubules, often fused seminiferous and large vacuoles [49].

Another gene involved with testicular gonadal development is DAX1 (also known as NROB1). This gene is located on the $X$ chromosome (p21.3) and encodes for an orphan nuclear receptor. Duplication of doses of this gene (individuals of karyotype XX) has been reported to act by directly inhibiting of $S F-1$ (transcription factor regulating $S O X 9$ ) (fig. 1). In this way, the two functional copies of $D A X 1$ prevent testicular formation [50]. This mechanism was validated in transgenic mice overexpressing $D A X 1$ with XY karyotype and female phenotype, where it was shown that the duplication of this gene was sufficient to block testicular differentiation [50] despite the chromosomal complement.

\section{Ovarian Development}

Female differentiation occurs once the germ cells enter meiosis, in the absence of $S R Y$ [51, 52], resulting in the inability of $S O X 9$ expression to reach a critical threshold, along with the expression of signaling factors such as RSPO1, WNT4 and FOXL2 that lead to ovary formation by differentiating precursor cells into granulosa cells and antagonizing testicular formation [33].

In XX gonads, the WNT4 and RSPO1 signaling factors favor and stabilize expression of the transcription factor CTNNB1 (known as B-catenin), which suppresses $S O X 9$ expression and regulates the transcription of WNT4-dependent genes. Thus, the presence of WNT4 antagonizes the male pathway by interfering with $S O X 9$ expression (fig. 1) [53, 54].

Although $S F-1$ main factor of the formation of the bipotential gonad remains essential for the differentiation of the testicles, its role in the maintenance of ovarian function also has been documented [55]. Expression of a single copy of the $S O X 9, S F-1$ and $W T 1$ genes, as well as duplication of the DAX1 and WNT4 genes result in $46, X Y$ gonadal dysgenesis $[56,57]$. While duplication of $S O X 9$ or $S O X 3$ genes may lead to DSD 46,XX testicular $[48,58,59]$.

Male reversion cases in XX individuals with $S R Y$-negative can occur due to pathogenic variant of loss of function in members of the ovarian pro-differentiation pathway or function-gain pathogenic variant in genes that mimic $S R Y$ activity [48].

\section{Epigenetic and DSD}

Epigenetics is the study of changes in gene expression not related to alterations in DNA sequence [60]. The main epigenetic mechanisms that regulate gene expression include: DNA methylation, covalent histone mod- 
ification and the presence of non-coding RNAs. During embryonic development, cells differentiate, acquire and maintain an identity through changes in gene expression, this process is fundamental to determine sex and differentiation.

DNA methylation is an epigenetic mechanism that occurs by transfer of a methyl group $\left(\mathrm{CH}_{3}\right)$ to carbon at the 5-position of the cytosine ring that occurs in the regulatory genes, as well as in the inter- and intra-genic sequences. This reaction is catalyzed by the family of enzymes DNA methyltransferases (DNMT1, DNMT3A, $D N M T 3 B$ ) [61]. In germ cells of mouse testicular or ovarian development, it has been determined that $D N$ $M T 3 A$ and $D N M T 3 L$ are actively involved in maintaining methylation of promoters requiring to be silenced for differentiation [62].

DNA methylation controls the expression of important genes for sexual differentiation, such as $S R Y$, during gonadal development and $\mathrm{X}$-chromosome inactivation in $\mathrm{XX}$ individuals [63]. Genes that regulate sex determination and differentiation have altered their expression in somatic cells, therefore, they are subject to a complex mechanism of regulation of expression. Reports in the literature related to murine gonadal development show that SRY, SOX9, NR5A1, DAX1 and WNT4 genes regulate their expression by methylation of their promoters in different cell contexts including cell differentiation processes of the development of tumor [63-65] and in specific cell differentiation spatiotemporal as shown in mouse embryos of $8.5 \mathrm{dpc}$, in which the $S R Y$ gene was not expressed secondary to hypermethylation of $5^{\prime}$-flanking region. However, at $11.5 \mathrm{dpc}$, this region was hypomethylated specifically in the gonad allowing expression of $S R Y$ and remained hypermethylated in tissues that do not express the $S R Y$ gene [63]. It is a sample of the possible alteration of genetic expression dependent on the time that can occur during sexual development due to epigenetic modifications.

Hypermethylation of the SRY gene causing abnormal gene expression resulted in the silencing of genes, DMRT1, SOX8, SOX9, NR5A1 and AMH, involved in the DSD XY in dogs. More recently, incomplete demethylation of $S R Y$ gene has been suggested to be one of the causes of DSD XY in these dogs [66].

Recent evidence suggests that histone modifications and chromatin regulation may also play roles in sexual differentiation [67]. Chromatin refers to the packaging of DNA and the modulation regulates the accessibility of the transcriptional machinery, thereby it regulates the activity of regulatory and functional DNA sequences. Co-

Diagnostic Approach of Disorders of

Sexual Development valent histone modifications, nucleosome repositioning and chromatin remodeling are fundamental epigenetic mechanisms to regulate the expression of specific genes and more extensive genomic regions. Specific enzymes (e.g. histone acetyltransferases and histone deacetylase) mediate reversible histone modifications [68].

Trimethylation of lysine 4 (H3K4me3) constitutes an important $\mathrm{H} 3$ modification associated with transcriptional activity, whereas methylation of lysine 9 (H3K9me) has the opposite effect. Tachibana et al. [69] found that XY mice deficient of the $\mathrm{H} 3 \mathrm{~K} 9$ demethylating enzyme developed as fertile females. RNA and protein expression analysis, showed that loss of $\mathrm{H} 3 \mathrm{~K} 9$ demethylation led to a strong downregulation of $S R Y$ expression during embryogenesis. Evidencing the role of histone methylation and demethylation on mammalian sex determination.

Recently, Kuroki et al. [70] reported that an XY mice deficient in JMJD1 A exhibits a male-to-female sexual reversion. JMJD1A is an enzyme that demethylates H3K9 (hallmark of transcriptionally silenced heterochromatin). The validation studies of the effect of JMJD1A by microarray, the rescue of the sex reversal phenotype by transgenic mouse and the chromatin immunoprecipitation analysis revealed that JMJD1A specifically contributes to the $S R Y$ activation by directly catalyzing $\mathrm{H} 3 \mathrm{~K} 9$ demethylation.

Another epigenetic mechanism are non-coding RNAs (ncRNAs), functional RNA molecules that are not translated into protein, including long non-codingRNAs (lncRNAs) and microRNA (miRNAs). IncRNAs such as XIST has been implicated in dosage sex compensation in Mus musculus [71], and some ncRNAs displaying sexually dimorphic expression have been identified [72]. However, the role of these ncRNAs during sex determination and gonadogenesis is at currently unknown and it will have to be characterized in the near future.

Despite the above, in relation to DSD, only DNA methylation analyses have been described in patients with alterations in $S R Y$ gene expression, recently in a woman with primary amenorrhea, with karyotype $46, X, \operatorname{inv}(Y)$ in whom methylation studies found higher methylation levels in $\mathrm{CpG}$ box located $3 \mathrm{Kbp}$ upstream from the $S R Y$ compared to their father [73].

\section{Approach to DSD}

The clinical evaluation of an individual with DSD or atypical genitalia begins with evaluation of vital signs, general physical examination, description of sexual char- 
Table 2. Genetic tests in the DSD approach

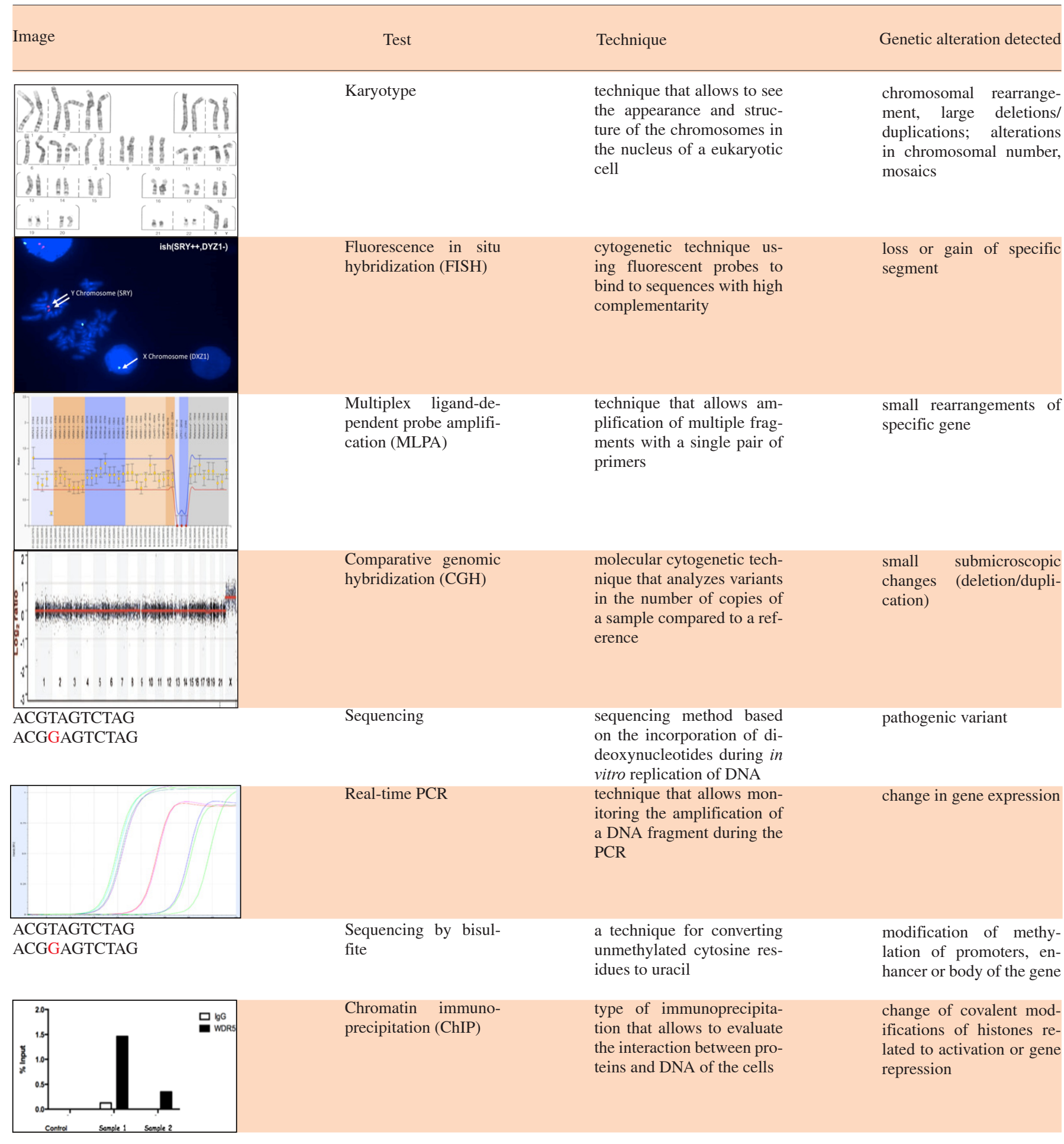

Images are results of the experiments of our research laboratory. 
acteristics and detailed evaluation of the perineal area consisting of observation, palpation and measurement, to be described according to Prader's classification [74] plus a complete clinical history including prenatal and family history [75] in a multidisciplinary group assessment (endocrinologist, urologist, geneticist, gynecologist, pediatrician, psychologist) to achieve an accurate diagnosis [50].

An extensive evaluation should be made when it is not possible to assign a sex or when the cytogenetic tests are inconclusive. Biochemical tests are good support for guiding diagnostic suspicion based on gonadal function, these measurements should be interpreted in relation to characteristics of the test and reference of normal values for gestational and chronological age. In some cases, serial measurements or stimulation tests may be necessary [76].

First-line tests include measurement of 17-hydroxyprogesterone, blood electrolytes, determination of AMH [77] and gonadotrophin levels, together with a cytogenetic study (karyotype) and an abdominal ultrasound in search of müllerian structures. Additional tests will be dependent on the results of the initial tests to guide the diagnostic suspicion [78].

The algorithm of the genetic study of DSD is defined according to the results of the sexual chromosomal complement [79] and fluorescence in situ hybridization analysis for regions of the $\mathrm{Y}$ chromosome, considering the percentage of $\mathrm{XX}$ individuals with $S R Y$ translocation. The next step of evaluation is followed by the study of specific genes involved in the gonadal development $(A R$, $S R Y, S F-1, W T 1, C Y P 21, S O X 9, D A X-1,5 \alpha$-reductase, among others) by traditional molecular research methods including Sanger sequencing combined with multiplex ligand dependent probe amplification [80] to identify abnormalities in the sequence or dosage of a gene, such as a deletion or duplication of genes [81, 82]. Although this genetic approach has generated expectations in clinical practice, results of sequencing and deletion/duplication analyses have identified the etiology of phenotypes in a very limited number of cases [33, 83]. Laino et al. [84] reported etiological diagnosis in $64 \%$ of the cases of a cohort of 88 individuals with DSD 46,XY and 46,XX using this diagnostic algorithm.

The hypothesis in relation to the above supposes that many genes causing DSD have not yet been identified or the techniques by which they are studied are insufficient. This is due to the complexity of genetic regulation that allows the functioning of a gene and therefore the expression of a phenotype.

Diagnostic Approach of Disorders of

Sexual Development
Although pathogenic variant, in most cases, is a process that affects the functionality of a gene, it is important to keep in mind that it is not the only that can alter it. With the discovery of the epigenetics, it is now clear that the mechanisms of transcriptional regulation (DNA methylation, covalent histone modification and the presence of ncRNAs, among others) can alter the expression of a gene, acting as true biological switches [60]. Therefore, new diagnostic options aim to evaluate the effect of epigenetic modifications and transcriptional factors on the expression of genes important for sexual determination are necessary to increase the detection of etiology in these individuals.

It is important to remember that epigenetic modifications are time- and tissue-specific, therefore in individuals with DSD these analyses should be performed on gonadal tissue, in conjunction with histological analysis, due to the high frequency of tumors derived from gonadal dysgenesis, considering that tumors by themselves have epigenetic modifications that can confuse the true etiology.

The above analyses may be performed in gonadal tissue by messenger RNA expression analysis by quantitative polymerase chain reaction or RNAseq, determination of the presence of chromatin tags (e.g., H3K4me1, H3K27Ac) by chromatin immunoprecipitation [33, 85] and determination of DNA methylation status by bisulfite modification - sequencing or methylation-specific polymerase chain reaction. This aims to increase the understanding of gonadal gene regulation networks, which will probably lead to contribute to the etiology of specific phenotypes of DSD. Description of some genetic tests that can be used in the DSD approach are shown in table 2.

\section{Conclusion}

DSD are complex conditions due to the bipotential nature morphology and functionality of the gonads. The characterization of chromosomal and molecular alterations, as well as the analysis of networks of gene regulation and their contribution in the phenotype of patients with DSD is a fundamental contribution in the understanding of the etiology of these clinical conditions that in the future will contribute to the improvement of the diagnosis, treatment and genetic counselling of the patient or his/her family.

Ideally, all patients should have studies of molecular biology and cytogenetics in the gonadal tissue, given the possibility of mosaicism as well as the specific tissue

Curr Urol 2019;13:169-178 
changes related to epigenetic modifications, this could aid in determining the etiology in many of the individuals in whom it is unknown.

\section{References}

$\checkmark 1$ Houk CP, Lee PA: Consensus statement on terminology and management: disorders of sex development. Sex Dev 2008;2:172-180.

$\checkmark 2$ Lee PA, Houk CP, Ahmed SF, Hughes IA: Consensus statement on management of intersex disorders. International Consensus Conference on Intersex. Pediatrics 2006;118:E488-E500.

-3 Lin-Su K, Lekarev O, Poppas DP, Vogiatzi MG: Congenital adrenal hyperplasia patient perception of 'disorders of sex development' nomenclature. Int J Pediatr Endocrinol 2015;2015:9.

-4 Dreger AD, Chase C, Sousa A, Gruppuso PA, Frader J: Changing nomenclature/ toxonomy for intersex: a scientific and clinical rationale. J Pediatr Endocrinol Metab 2005; 18:729-733.

5 Hughes IA: Disorders of sexual differentiation. Horm Res Paediatr 2007;67(suppl 1):91-95.

76 Sax L: How common is intersex? A response to Anne Fausto-Sterling. J Sex Res 2002;39:174-178.

$\checkmark 7$ Nordenvall AS, Frisen L, Nordenstrom A, Lichtenstein P, Nordenskjold A: Population based nationwide study of hypospadias in Sweden, 1973 to 2009: incidence and risk factors. J Urol 2014;191:783-789.

$\checkmark 8$ Pang SY, Wallace MA, Hofman L, Thuline HC, Dorche C, Lyon IC, Dobbins RH, Kling S, Fujieda K, Suwa S: Worldwide experience in newborn screening for classical congenital adrenal hyperplasia due to 21-hydroxylase deficiency. Pediatrics 1988;81:866-874.

$\checkmark 9$ Thyen U, Lanz K, Holterhus PM, Hiort O: Epidemiology and initial management of ambiguous genitalia at birth in Germany. Horm Res 2006;66:195-203.

$>10$ Kyriakou A, Lucas-Herald A, McGowan R, Tobias E, Ahmed F: Disorders of sex development: advances in genetic diagnosis and challenges in management. Adv Genom Gen 2015;5:165-177.
11 Eggers S, Sadedin S, van den Bergen J, Robevska G, Ohnesorg T, Hewitt, Lambeth L, Bouty A, Knarston IM, Tan TY, Cameron F, Werther G, Hutson J, O'Connell M, Grover SR, Heloury Y, Zacharin M, Bergman P, Kimber C, Brown J, Webb N, Hunter MF, Srinivasan S, Titmuss A, Verge CF, Mowat D, Smith G, Smith J, Ewans L, Shalhoub C, Crock P, Cowell C, Leong GM, Ono M, Lafferty AR, Huynh T, Visser U, Choong CS, McKenzie F, Pachter N, Thompson EM, Couper J, Baxendale A, Gecz J, Wheeler BJ, Jefferies C, MacKenzie K, Hofman P, Carter P, King RI, Krausz C, van Ravenswaaij-Arts CM, Looijenga L, Drop S, Riedl S, Cools M, Dawson A, Juniarto AZ, Khadilkar V, Khadilkar A, Bhatia V, Dũng VC, Atta I, Raza J, Thi Diem Chi N, Hao TK, Harley V, Koopman P, Warne G, Faradz S, Oshlack A, Ayers KL, Sinclair AH: Disorders of sex development: insights from targeted gene sequencing of a large international patient cohort. Genome Biol 2016;17:243.

12 Woodward M, Patwardhan N: Disorders of sex development. Surgery (Oxford) 2010;28: 396-401.

13 MacLaughlin DT, Donahoe PK: Sex determination and differentiation. N Engl J Med 2004;350:367-378.

14 Wilhelm D, Palmer S, Koopman P: Sex determination and gonadal development in mammals. Physiol Rev 2007;87:1-28.

15 Biason-Lauber A: Control of sex development. Best Pract Res Endocrinol Metab 2010; 24:163-186.

$>16$ Houmard B, Small C, Yang L, Naluai-Cecchini T, Cheng E, Hassold T, Griswold M: Global gene expression in human fetal testis and ovary. Biol Reprod 2009;81:438-443.

17 Brennan J, Capel B: One tissue two fates: molecular genetic events that underlie testis versus ovary development. Nat Rev Genet 2004:5:509-521.

-18 Shahid M, Dhillion VS, Jain N, Hedau S, Diwakar S, Sachdeva P, Batra S, Das BC, Husain SA: Two new novel point mutations localized upstream and downstream of the HMG box region of the SRY gene in three Indian 46,XY females with sex reversal and gonadal tumour formation. Mol Hum Reprod 2004;10:521-526.
19 Yadav BR, King WA, Betteridge KJ: Relationships between the completion of first cleavage and the chromosomal complement, sex, and developmental rates of bovine embryos generated in vitro. Mol Reprod Dev 1993;36:434-439.

20 Pergament E, Fiddler M, Cho N, Johnson D, Holmgren WJ: Sex differentiation and preimplantation cell growth. Hum Reprod 1994;9:1730-1732.

21 Thornhill AR, Burgoyne PS: A paternally imprinted X chromosome retards the development of the early mouse embryo. Development 1993;118:171-174.

-22 Erickson RP, Strnatka D: Insulin receptor-related (Irr) is expressed in pre-implantation embryos: a possible relationship to "growth factor Y" and sex determination. Mol Reprod Dev 2011;78:552.

23 Shen WH, Moore CC, Ikeda Y, Parker KL, Ingraham HA: Nuclear receptor steroidogenic factor 1 regulates the mullerian inhibiting substance gene: a link to the sex determination cascade. Cell 1994;77:651-661.

24 Jordan T, Hanson I, Zaletayev D, Hodgson S, Prosser J, Seawright A, Hastie N, van Heyningen V: The human PAX6 gene is mutated in two patients with aniridia. Nat Genet 1992;1:328-332.

25 Birk OS, Casiano DE, Wassif CA, Cogliati T, Zhao L, Zhao Y, Grinberg A, Huang S, Kreidberg JA, Parker KL, Porter FD, Westphal H: The LIM homeobox gene Lhx9 is essential for mouse gonad formation. Nature 2000;403:909-913.

26 Ahmed SF, Hughes IA: The genetics of male undermasculinization. Clin Endocrinol 2002;56:1-10.

27 Polanco JC, Koopman P: Sry and hesistant begining of male development. Dev Biol 2007;302:13-24.

28 Morais da Silva S, Hacker A, Harley V, Goodfellow P, Swain A, Lovell-Badge R: Sox 9 expression during gonadal development implies a conserved role for the gene in testis differentiation in mammals and birds. Nat Genet 1996;14:62-68. 
29 Yao HH: The pathway to femaleness: current knowledge on embryonic development of the ovary. Mol Cell Endocrinol 2005;230:87-93.

>30 Edson MA, Nagaraja AK, Matzuk MM: The mammalian ovary from genesis to revelation.. Endocr Rev 2009;30:624-712.

-31 Maatouk DM, DiNapoli L, Alvers A, Parker K, Taketo MM, Capel B: Stabilization of beta-catenin in XY gonads causes maleto-female sex-reversal. Hum Mol Genet 2008;17:2949-2955.

-32 Sekido R, Lovell-Badge R: Sex determination and SRY: down to a wink and a nudge? Trends Genet 2009;25:19-29.

-33 Arboleda VA, Sandberg DE, Vilain E: DSDs: genetics, underlying pathologies and psychosexual differentiation. Nat Rev Endocrinol 2014;10:603-615.

>34 Qin Y, Kong LK, Poirier C, Truong C, Overbeek PA, Bishop CE: Long-range activation of Sox9 in Odd Sex (Ods) mice. Hum Mol Genet 2004;13:1213-1218.

-35 McClelland K, Bowles J, Koopman P: Male sex determination: insights into molecular mechanisms. Asian J Androl 2012;14:164 171.

>36 Salehi L, Scarciolla O, Vanni G, Nardone A, Frajese G, Novelli G, Stuppia L: Identification of a novel mutation in the SRY gene in a 46, XY female patient. Eur J Med Genet 2006;49:494-498.

-37 Hermus R, de Leeuw BH, Stoop H, Bernard $\mathrm{P}$, van Doorn HC, Bruggenwirth HT, Drop SL, Oosterhuis JW, Harley VR, Looijenga LH: A novel SRY missense mutation affecting nuclear import in a 46, XY female patient with bilateral gonadoblastoma. Eur J Hum Genet 2009;17:1642-1649.

>38 Kashimada K, Koopman P: Sry: the master switch in mammalian sex determination. Development 2010;137:3921-3930.

>39 Tevosian SG, Albrecht KH, Crispino JD, Fujiwara Y, Eicher EM, Orkin SH: Gonadal differentiation, sex determination and normal Sry expression in mice require direct interaction between transcription partners GATA4 and FOG2. Development 2002;129:4627-4634.

-40 Boyer A, Pilon N, Raiwet DL, Lussier JG, Silversides DW: Human and pig SRY 5 flanking sequences can direct reporter transgene expression to the genital ridge and to migrating neural crest cells. Dev Dyn 2006;235:623-632.

-41 Knower KC, Kelly S, Ludbrook LM, Bagheri-Fam S, Sim H, Bernard P, Sekido R, Lovell-Badge R, Harley VR: Failure of SOX9 regulation in 46XY disorders of sex development with SRY, SOX9 and SF1 mutations. PLoS One 2011;6:e17751.

42 Frade E: Molecular analysis of genes involved in sexual determination and differentiation in SRY-negative patients with the disorders of sex development 46,XX testicular e ovotesticular. Hospital das Clínicas da Faculdade de Medicina da USP (HCFMUSP), São Paulo, Secretaria da Saúde, 2014.
43 Stevanovic M, Lovell-Badge R, Collignon $\mathrm{J}$, Goodfellow PN: SOX3 is an X-linked gene related to SRY. Hum Mol Genet 1993;2:2013-2018.

44 Collignon J, Sockanathan S, Hacker A, Cohen-Tannoudji M, Norris D, Rastan S, Stevanovic M, Goodfellow PN, Lovell-Badge R: A comparison of the properties of Sox-3 with Sry and two related genes, Sox-1 and Sox-2. Development 1996;122:509-520.

-45 Graves JA: Interactions between SRY and SOX genes in mammalian sex determination. Bioessays 1998;20:264-269.

46 McElreavey K, Vilain E, Abbas N, Herskowitz I, Fellous M: A regulatory cascade hypothesis for mammalian sex determination: SRY represses a negative regulator of male development. Proc Natl Acad Sci 1993;90:3368-3372.

47 Bergstrom DE, Young M, Albrecht KH, Eicher EM: Related function of mouse SOX3, SOX9, and SRY HMG domains assayed by male sex determination. Genesis 2000;28:111-114.

48 Sutton E, Hughes J, White S, Sekido R, Tan J, Arboleda V, Rogers N, Knower K, Rowley L, Eyre H, Rizzoti K, McAninch D, Goncalves J, Slee J, Turbitt E, Bruno D, Bengtsson H, Harley V, Vilain E, Sinclair A, Lovell-Badge $\mathrm{R}$, Thomas P: Identification of SOX3 as an $\mathrm{XX}$ male sex reversal gene in mice and humans. J Clin Invest 2011;121:328-341.

49 Weiss J, Meeks JJ, Hurley L, Raverot G, Frassetto A, Jameson J: Sox3 is required for gonadal function, but not sex determination, in males and females. Mol Cell Biol 2003;23:8084-8091.

50 Ludbrook LM, Bernard P, Bagheri-Fam S, Ryan J, Sekido R, Wilhelm D, Lovell-Badge R, Harley VR: Excess DAX1 leads to XY ovotesticular disorder of sex development (DSD) in mice by inhibiting steroidogenic factor-1 (SF1) activation of the testis enhancer of SRY- box-9 (Sox9). Endocrinology 2012;153:1948-1958.

51 Yao HH, DiNapoli L, Capel B: Meiotic germ cells antagonize mesonephric cell migration and testis cord formation in mouse gonads. Development 2003;130:5895-5902.

52 Nef S, Schaad O, Stallings NR, Cederroth CR, Pitetti JL, Schaer G, Malki S, Dubois-Dauphin M, Boizet-Bonhoure B, Descombes P, Parker KL, Vassalli JD: Gene expression during sex determination reveals a robust female genetic program at the onset of ovarian development. Dev Biol 2005;287:361-377.

53 Cederroth CR, Pitetti JL, Papaioannou MD, Nef S: Genetic programs that regulate testicular and ovarian development. Mol Cell Endocrinol 2007;265-266:3-9.

54 Schuijers J, Clevers H: Adult mammalian stem cells: the role of Wnt, Lgr5 and Rspondins. EMBO J 2012;31:2685-2696.
55 Lourenco D, Brauner R, Lin L, De Perdigo A, Weryha G, Muresan M, Boudjenah R, Guerra-Junior G, Maciel-Guerra AT, Achermann JC, McElreavey K, Bashamboo A: Mutations in NR5A1 associated with ovarian insufficiency. N Engl J Med 2009;360:1200-1210.

56 Achermann JC, Ito M, Ito M, Hindmarsh PC, Jameson JL: A mutation in the gene encoding steroidogenic factor-1 causes XY sex reversal and adrenal failure in humans. Nat Genet 1999;22:125-126.

57 Foster JW, Dominguez-Steglich MA, Guioli S, Kwok C, Weller PA, Stevanovi M, Weissenbach J, Mansour S, Young ID, Goodfellow PN: Campomelic dysplasia and autosomal sex reversal caused by mutations in an SRY-related gene. Nature 1994;372:525-530.

58 Jordan BK, Mohammed M, Ching SS, Délot E, Chen XN, Dewing P, Swain A, Rao PN, Elejalde BR, Vilain E: Up-regulation of WNT-4 signaling and dosage-sensitive sex reversal in humans. Am J Hum Genet 2011;68:1102-1109.

59 Huang B, Wang S, Ning Y, Lamb AN, Bartley J: Autosomal XX sex reversal caused by duplication of SOX9. Am J Med Genet 1999;87:349-353.

60 Allis D, Caparros M, Jenuwein T, Reinberg D: Epigenetics, ed 2. Cold Spring Harbor Laboratory Press, New York, 2015.

61 Jin B, Li Y, Robertson KD: DNA Methylation: superior or subordinate in the epigenetic hierarchy? Genes Cancer 2011;2:607-617.

62 La Salle S, Trasler JM: Dynamic expression of DNMT3a and DNMT3b isoforms during male germ cell development in the mouse. Dev Biol 2006;296:71-78.

63 Nishino K, Hattori N, Tanaka S, Shiota K DNA methylation-mediated control of Sry gene expression in mouse gonadal development. J Biol Chem 2004;279:22306-22313.

-64 Aleman A, Adrien L, López-Serra L, Cordon C, Esteller M, Belbin TJ, Sanchez-Carbayo M: Identification of DNA hypermethylation of SOX9 in association with bladder cancer progression using $\mathrm{CpG}$ microarrays. $\mathrm{Br} \mathrm{J}$ Cancer 2008;98:466-473.

65 Yu H, Pask AJ, Shaw G, Renfree MB: Comparative Analysis of the mammalian WNT4 promoter. BMC Genomics 2009;10:416.

66 Jeong $\mathrm{YH}, \mathrm{Lu} \mathrm{H}$, Park CH, Li M, Luo H, Kim JJ, Liu S, Ko KH, Huang S, Hwang IS, Kang MN, Gong D, Park KB, Choi EJ, Park JH, Jeong YW, Moon C, Hyun SH, Kim NH, Jeung EB, Yang H, Hwang WS, Gao F: Stochastic anomaly of methylome but persistent SRY hypermethylation in disorder of sex development in canine somatic cell nuclear transfer. Sci Rep 2016;6:31088.

-67 Qureshi IA, Mehler MF: Genetic and epigenetic underpinnings of sex differences in the brain and in neurological and psychiatric disease susceptibility. Prog Brain Res 2010;186:77-95. 
68 Mehler MF: Epigenetic principles and mechanisms underlying nervous system functions in health and disease. Prog Neurobiol 2008;86:305-341.

69 Tachibana M, Matoba S, Akiyoshi M, Matsumura Y, Miyachi H, Mise N: The histone demethylase Jmjd1a controls sex determination via activating Sry expression. In Proceedings 6th International Symposium on Sex Determination, Kona, Hawaii, 2012, p23.

-70 Kuroki S, Matoba S, Akiyoshi M, Matsumura Y, Miyachi H, Mise N, Abe K, Ogura A, Wilhelm D, Koopman P, Nozaki M, Kanai Y, Shinkai Y, Tachibana M: Epigenetic regulation of mouse sex determination by the histone demethylase Jmjd1a. Science 2013;341:1106-1109.

-71 Piferrer F: Epigenetics of sex determination and gonadogenesis. Dev Dyn 2013;242:360370.

-72 Chen H, Palmer JS, Thiagarajan RD, Dinger ME, Lesieur E, Chiu H, Schulz A, Spiller C, Grimmond SM, Little MH, Koopman P, Wilhelm D: Identification of novel markers of mouse ovary development. PLoS One 2012;7:e41683.

-73 Gimelli G, Giorda R, Beri S, Gimelli S, Zuffardi O: A 46,X,inv(Y) young woman with gonadal dysgenesis and gonadoblastoma: cytogenetics, molecular, and methylation studies. Am J Med Genet A 2006;140:40-45.

74 Hutson JM, Grover SR, O'Connell M, Pennell SD: Malformation syndromes associated with disorders of sex development. Nat Rev Endocrinol 2014;10:476-487.
75 Ahmed SF, Achermann JC, Arlt W, Balen AH, Conway G, Edwards ZL, Elford S, Hughes IA, Izatt L, Krone N, Miles HL, O'Toole S, Perry L, Sanders C, Simmonds M, Wallace AM, Watt A, Willis D: UK guidance on the initial evaluation of an infant or an adolescent with a suspected disorder of sex development. Clin Endocrinol (Oxf) 2011;75:12-26.

76 Lee PA, Nordenström A, Houk CP, Ahmed SF, Auchus R, Baratz A, Baratz Dalke K, Liao LM, Lin-Su K, Looijenga LH 3rd, Mazur T, Meyer-Bahlburg HF, Mouriquand P, Quigley CA, Sandberg DE, Vilain E, Witchel S: Global disorders of sex development update since 2006: perceptions, approach and care. Horm Res Paediatr 2016;85:158-180.

77 Josso N, Rey R, Picard JY: Testicular anti-Müllerian hormone: clinical applications in DSD. Semin Reprod Med 2012;30:364-373.

78 Lucas-Herald AK, Ahmed SF: Sex assignment in disorders of sex development. Chichester, John Wiley \& Sons, 2012.

79 Ahmed SF, Rodie M: Investigation and initial management of ambiguous genitalia. Best Pract Res Clin Endocrinol Metab 2010;24:197-218.

80 Tannour-Louet M, Han S, Corbett ST, Louet JF, Yatsenko S, Meyers L, Shaw CA, Kang $\mathrm{SH}$, Cheung SW, Lamb DJ: Identification of de novo copy number variants associated with human disorders of sexual development. PLoS One 2010;5:e15392.

81 Tobias ES, McElreavey K: Next generation sequencing for disorders of sex development. Endocr Dev 2014;27:53-62.

- 82 Arboleda VA, Lee H, Sánchez FJ, Délot EC, Sandberg DE, Grody WW, Nelson SF, Vilain E: Targeted massively parallel sequencing provides comprehensive genetic diagnosis for patients with disorders of sex development. Clin Genet 2013;83:35-43.
83 Baxter RM, Vilain E: Translational genetics for diagnosis of human disorders of sex development. Annu Rev Genomics Hum Genet 2013;14:371-392.

84 Laino L, Majore S, Preziosi N, Grammatico B, De Bernardo C, Scommegna S, Rapone AM, Marrocco G, Bottillo I, Grammatico P: Disorders of sex development: a genetic study of patients in a multidisciplinary clinic. Endocr Connect 2014;3:180-192.

85 Norling A, Hirschberg AL, Iwarsson E, Wedell A, Barbaro M: CBX2 gene analysis in patients with $46, \mathrm{XY}$ and $46, \mathrm{XX}$ gonadal disorders of sex development. Fertil Steril 2013;99:819-826.e3.

-86 Hughes IA, Houk C, Ahmed SF, Lee PA: Consensus statement on management of intersex disorders. Arch Dis Child 2006;91:554-563.

87 Fernandez N, Moreno O, Rojas A, Céspedes C, Forero C, Mora L, Suarez F, Auli J, Perez $\mathrm{J}$ : Transdisciplinary management of patients with disorders of sexual development in Colombia. Limiting factors for appropriate management. Urol Colomb 2017;26:164-168.

88 Guerra-Junior G, Maciel-Guerra AT: The role of the pediatrician in the management of children with genital ambiquities. J Pediatr (Rio J) 2007;83(5 suppl):S184-191. 